\title{
Giresun Kıyı Şeridindeki Patella sp.’nin Et Kalitesi Değişiminin Mevsimsel Olarak Belirlenmesi ${ }^{[*]}$
}

Atıf yapmak için: Mutlu, C., Şen, F.G. \& Kalkan, S. (2021). Giresun Kıyı Şeridindeki Patella sp. nin Et Kalitesi Değişiminin Mevsimsel Olarak Belirlenmesi. Anadolu Çev. ve Hay. Dergisi, 6(2), 261-265.

How to cite: Mutlu, C., Şen, F.G. \& Kalkan, S. (2021). Determination of Seasonal Variation in the Meat Quality of Patella sp. from Giresun Region. J. Anatolian Env. and Anim. Sciences, 6(2), 261-265.

\section{*Sorumlu yazarın:}

Cengiz MUTLU

Giresun Üniversitesi, Mühendislik Fakültesi,

Çevre Mühendisliği Bölümü, Giresun,

Türkiye

凶: cengiz.mutlu@ giresun.edu.tr
Öz: Patellalar dünyanın birçok bölgesinde insan gıdası olarak tüketilen canlılardandır fakat literatür incelendiğinde, ekonomik olarak yeterince değerlendirilmeyen Patella sp. örneklerinin et kalitesi açısından değerlendirildiği bir çalışma bulunmamaktadır. Bu nedenle çalışmamızda, Patella sp. örneklerinin fiziksel, kimyasal ve mikrobiyolojik özelliklerinin araştırılması amaçlanmıştır. Araştırma sonuçlarına göre, Giresun ilinden üç farklı istasyondan (Sanayi, Eynesil, Piraziz) toplanan ve farklı mevsimlerde (ilkbahar, yaz, sonbahar, kış) analize alınan Patella sp. örneklerinin su aktivitesi değerleri 0,9909-0,9989, pH değerleri 6,87-7,76, kuru madde değerleri \%16,68-27,76, kül değerleri \%1,64-2,55 ve protein değerleri ise \%3,65-15,40 olarak belirlenmiştir. Örneklerin mikrobiyolojik analizleri sonucunda, toplam mezofilik aerobik bakteri sayısının 7,98-8,96 log kob/g, koliform grup bakteri sayısının 1,15-2,38 log kob/g, E.coli sayı ortalamalarının 0,30-24,00 EMS/g, toplam psikrofil bakteri sayısının 1,35-2,66 log kob/g, ve maya-küf sayısının ise 5,09-6,76 log kob/g değerleri arasında olduğu tespit edilmiştir. Sonuç olarak, Patella sp. örneklerinin et tüketimi açısından uygunluğunun değerlendirildiği çalışmamızda, örneklerin fizikokimyasal açıdan tüketime uygunluk gösterdiği belirlenmiştir. Fakat örnekler mikrobiyolojik olarak tüketim sınırları üzerinde değerlere sahiptirler ve bu değerler istasyonlar ile mevsimlere bağlı olarak da değişiklik göstermektedir.

Anahtar kelimeler: Et kalitesi, fizikokimyasal özellikler, mikrobiyolojik özellikler, Patella sp.

\section{Determination of Seasonal Variation in the Meat Quality of Patella sp. from Giresun Region}

*Corresponding author's:

Cengiz MUTLU

Giresun University, Faculty of Engineering, Department of Environmental Engineering, Giresun, Turkey

$凶$ : cengiz.mutlu@giresun.edu.tr

\begin{abstract}
Patella sp. are among the creatures consumed as human food in many parts of the world, but when the literature is examined, Patella sp. there is no study in which samples were evaluated in terms of meat quality. Therefore, in our study, it was aimed to investigate the physical, chemical and microbiological properties of the Patella sp. samples. According to the results of the study, the water activity (0.9909-0.9989), $\mathrm{pH}(6.87-7.76)$, dry matter (16.68$27.76 \%)$, ash (1.64-2.55\%) and protein (3.65-15.40\%) values of the Patella sp. samples, was collected from three different stations (Sanayi, Eynesil, Piraziz) from Giresun province and analyzed in different seasons (spring, summer, autumn, winter). As a result of the microbiological analysis of the samples, the total mesophilic aerobic bacteria values of the Patella sp. samples were found to be 7.98-8.96 log cfu/g. The coliform group bacteria number of the samples was determined as 1.15-2.38 log cfu/g, E. coli number averages of the samples are 0.30-24.00 EMS/g. Total psychrophil bacterial values, it is seen that they have values between $1.35-2.66 \mathrm{log} \mathrm{cfu} / \mathrm{g}$ Patella sp. has a value between 5.09-6.76 log cfu/g in terms of yeast-mold number. Consequently, in our study, the suitability of the Patella sp. samples in terms of meat consumption was evaluated and it was determined that the samples were suitable for consumption in terms of physicochemical. However, the samples have values above the consumption limits microbiologically and these values also vary depending on the stations and the seasons.
\end{abstract}




\section{GíRíş}

Dünya nüfusunun artışı ile beraber, gıda ihtiyacının karşılanabilmesi için gıda üretimi de artmalıdır. İnsan beslenmesi açısından gida kaynaklarının arasında su ürünlerinin önemi büyüktür. $\mathrm{Su}$ ürünleri protein içeriği bakımından zengindir. Yağda çözünen A, D, E, K vitaminler ile kalsiyum, iyot, fosfor gibi önemli mineralleri içermektedirler. Yapılarındaki doymamış yă̆ asitleri nedeniyle kandaki kolesterol seviyesini azaltması ve düşük kalori değerlerine sahip olmalarından dolayı, tüketiciler tarafindan diyet gidalar olarak da tercih edilmektedirler (Göğüş \& Kolsarıcı, 1992). Balıkçılık dışında diğer avlanan deniz mahsullerinden (kum midyesi; akivades ve beyaz kum midyesi, deniz salyangozu, karidesler; tüm türler, midye; kara ve killi midye ve mürekkep balığ $)$ toplam üretimde $\% 73,75$ oranıyla en yüksek paya Kum Midyesi sahiptir. Diğer en yüksek avlanan su ürünü ise $\% 16$ oranıla deniz salyangozudur (TÜİK, 2020). Tüketime uygunluk açısından değerlendirildiğinde, midyeler yaşadıkları bölgeye göre çeşitli bakterileri barındırabilmektedirler. Av yapılan bölge midye kalitesini önemli ölçüde etkilemektedir (Mol, 2006). Kaliteli midye üretimi için; suların güvenliğinin sağlanmasının ve suların güvenliğini izlemenin önemi ve midyelerin uygun şekilde işlenmediği zaman insan sağlığı açısından risk olan çok sayıda patojen mikroorganizma içerebileceği Kılınç vd., (2014) tarafından açıklanmıştır. Genel olarak su kaynaklarının fiziksel, kimyasal ve mikrobiyolojik kalitesi, evsel ve katı atıklardan birinci derecede etkilenmektedir. Özellikle Giresun il sınırları dahilinde su kaynaklarındaki fizikokimyasal değişim (Mutlu vd., 2018; Uncumusaoglu vd., 2016; Uncumusaoğlu \& Akkan, 2017), mikrobiyolojik değişim (Akkan \& Çolaker, 2020; Akkan \& Topkaraoğlu, 2019; Akkan vd., 2019) ve hatta tatlısu, deniz suyu ve balık örneklerinden izole edilen bakterilerde yüksek antibiyotik direnç profilinin rapor edildiği bilinmektedir (Akkan, 2017; Akkan \& Mutlu, 2016; Sipahi vd., 2013). İlaveten, Polat \& Akkan (2016) yapmış oldukları çalışmada Giresun kıyı şeridi deniz suyunda ağır metal ve anyonik deterjan kalıntısı tespit etmişlerdir.

Limpetler, dünya çapında kayalık kıyılardaki en iyi bilinen deniz otoburları arasındadır (Jenkins vd., 2005). Diyatomlar, sporlar, makroalg ve omurgasızların diğer propagülleri dahil olmak üzere esas olarak siyanobakteriler ve mikroalglerden oluşan mikrobiyal biyofilmlerle beslenirler (Jenkins vd., 2005; Coleman vd., 2006). Ülkemizde Çin şapkası veya taş midyesi olarak adlandırılan patella türleri; kayalık sahillerde deniz içerisinde ya da deniz seviyesinin hemen üst kısmında bulunurlar (Öztürk \& Ergen, 1999). Deniz kıyılarındaki kayalık gel-git bölgelerinde, dalgalar tarafindan ıslatılan taşlar üzerinde, supralittoral zonda, mediolittoral zonda ve üstinfralittoral zonda bulunurlar. Patellidae familyası dünyada 34 tür ile, patella cinsi 9 tür ile temsil edilir. Akdeniz'de 6, ülkemizde ise 3 tür ile temsil edildiği bildirilmektedir (Güngör, 2011 ).

Patellalar dünyanın birçok bölgesinde insan gidası olarak tüketilen canlılardandır (Gözler vd., 2003). Literatüre bakıldığında Dünya'da ve Türkiye'de midye ve işlenmiş midye üzerine yapılmış birçok çalışma bulunmaktadır (Kılınç vd., 2018). Fakat Patella sp.'nın et kalitesi açısından değerlendirildiği herhangi bir çalışma bulunmamaktadır. $\mathrm{Bu}$ çalışmada, kıyı sularımızdaki gel-git alanlarında dolgu ve doğal kayaların üzerine kendini yapıştırarak yaşayan ve Türkiye'de yeterince ekonomik olarak değerlendirilmeyen Patella sp.'nin et kalitesi açısından değerlendirilmesi amaçlanmıştır. Bu amaçla çalışmada; Giresun kıyı şeridinde yer alan 3 farklı bölgeden toplanan (Sanayi, Espiye ve Piraziz istasyonları) Patella sp.'ların fiziksel, kimyasal ve mikrobiyolojik analizleri yapılarak mevsimsel açıdan et kalitesindeki değişimler yorumlanmıştır.

\section{MATERYAL VE METOT}

Materyal: Araştırma, 4 mevsimi kapsayacak şekilde Nisan 2019-Ocak 2020 tarihleri arasında (sonbahar, kış, ilkbahar, yaz mevsimlerinde) Giresun ili sahil şeridindeki deniz ile irtibatlı kayalık alanlardan (gel-git alanları) temin edilmiştir. Bu amaçla örnekleme istasyonu olarak Giresun Merkez (Sanayi önü) koordinat (4054'49.4"K, 38²5'29.2"D), Eynesil kıyı şeridinde (41 $\left.{ }^{\circ} 04^{\prime} 05,5^{\prime \prime K}, 39^{\circ} 08^{\prime} 46,7^{\prime \prime D}\right)$ koordinattan ve Piraziz kiyı şeridindeki $\left(40^{\circ} 56^{\prime} 59,2^{\prime \prime} \mathrm{K}, \quad 38^{\circ} 09^{\prime} 41,6^{\prime \prime} \mathrm{D}\right)$ koordinattan seçilmiştir.

Fiziksel analizler: Patella sp. örneklerinin su aktivite değerleri, $25{ }^{\circ} \mathrm{C}$ sicaklıkta, Aqualab 4TE (Meter Group, Inc., USA) marka su aktivitesi tayin cihazı kullanılarak belirlenmiştir. Analiz periyodu boyunca örneklerinin, beyaz standart yüzey üzerinde, HunterLab MiniScan EZ (Hunter Assoctes Laboratory, Inc., USA) ile $L^{*}$ (açıklık) , $a^{*}$ (kırmızı-yeşil) ve $b^{*}$ (sarı-mavi) renk parametreleri ölçülmüştür. Patella sp. örneklerinin renk değişimleri $\left(\Delta E^{*}\right)$, aşağıda verilen eşitlikten (1.1) yararlanılarak hesaplanmıştır.

$$
\Delta E^{*}=\left[\left(L_{o}^{*}-L^{*}\right)^{2}+\left(a_{o}^{*}-a^{*}\right)^{2}+\left(b_{o}^{*}-b^{*}\right)^{2}\right]^{1 / 2}
$$

Eşitlikte yer alan $L_{o}, a_{o}$ ve $b_{o}$ standart yüzeyin renk parametreleri iken, $L, a$ ve $b$ değerleri, örneklerin renk parametreleridir.

Kimyasal analizler: Patella sp. örneklerinin $\mathrm{pH}$ değerleri, 10 gram örnek, $90 \mathrm{~mL}$ distile suda homojen hale getirildikten sonra, Mettler-Toledo (Mettler-Toledo International Inc., Switzerland) marka $\mathrm{pH}$ metre ile yapılmıştır. Örneklerin ham kuru madde miktarları ile ham 
kül analizleri Süleyman (2016)'a göre yapılmıştır. Araştırmada Patella sp. örneklerinin protein tayini A.O.A.C., 981.10 (1984) metoduna göre, Kjeldahl metoduyla yapılmış olup, örnekler 6,25 çarpım faktörü ile çarpılıp hesaplanmış, sonuçlar kuru madde esasına göre belirlenmiştir.

Mikrobiyolojik analizler: Laboratuvara aseptik şartlarda getirilen numuneler, steril bir cam kap içine alınarak kabın ağzı hijyenik olarak kapatılmışıtır. Aseptik şartlarda $10 \mathrm{~g}$ örnek, $90 \mathrm{~mL}$ steril Maximum Recovery Diluent Broth (MRD, Merck) besiyeri ile steril Stomacher poşetine aktarılmıştır. Stomacher'de 60 saniye homojenize edilerek elde edilen solüsyondan, steril bir pipetle $1 \mathrm{~mL}$ çekilerek $9 \mathrm{~mL}$ MRD Broth (Merck) bulunan deney tüplerine aktarılmıştır. Böylece önce $10^{2}$ ' lik, aynı işlemler tekrarlanarak $10^{7}$ ye kadar seri dilüsyonlar elde edilmiştir (ISO 6887-1, 1999). Patella sp. örneklerinin toplam mezofilik aerobik bakteri sayısı (TMAB) Plate Count Agar (PCA, Merck) besiyerinde yayma yöntemi uygulanarak, 37 ${ }^{\circ} \mathrm{C}$ 'de 24 saat inkübasyon sonucunda oluşan koloniler sayllarak belirlenmiştir (FDA, 1995). Toplam psikrofilik bakteri sayıs1, Plate Count Agar (PCA, Merck) besiyerinde yayma yöntemi uygulanarak $7^{\circ} \mathrm{C}$ 'de 10 gün inkübasyon sonrasında oluşan koloniler sayılarak belirlenmiştir (Turan ve Onay, 2015). Koliform grup bakteri sayısının belirlenmesinde, Violet Red Bile Agar (VRB Agar, Merck) besiyeri kullanılarak, petri kutuları $37^{\circ} \mathrm{C}$ 'de 24 saat inkübe edilmiş ve sayım sonuçları alınmıştır (Özen \& Çoşkun, 2014). Patella sp. örneklerinin E. coli sayımın yapılması için 3'lü Tüp En Muhtemel Sayım (EMS) yöntemi kullanılmıştır. Bu amaçla $9 \mathrm{~mL}$ olarak hazırlanan, durham tüpü içeren steril Laurel Sulfate Broth (LST) besiyerlerine hazırlanan seri dilüsyonlardan 1'er $\mathrm{mL}$ olarak ekim yapılmıştır. Ekim sonras $37^{\circ} \mathrm{C}^{\prime}$ de 24 saat süreyle inkübasyona birakılan tüpler berraklık/bulanıklık ve gaz oluşumu açısından kontrol edilmiştir. Bulanıklık ve gaz oluşumu tüpler pozitif olarak kabul edilmiştir ve bu pozitif tüplere $1 \mathrm{~mL}$ kovacs indol ayıracı damlatılmıştır. 1 dakikalık bekletme süresi sonunda tüp yüzeyinde vişne çürüğü rengi oluşumu gözlenen tüpler E.coli pozitif olarak kabul edilmiş ve EMS tablosundanyararlanılarak sonuç EMS/g olarak verilmiştir. Toplammaya ve küf sayımı için \%10'luk tartarik asit ile pH'sı 3,5'eayarlanmış, Patato Dekstroz Agar (PDA, Merck)kullanılmıştır. Ekimi yapılan petri kutuları $25^{\circ} \mathrm{C}$ 'de 5 güninkübe edilerek toplam maya ve küf sayısı tespit edilmiştir

(İnal, 1992).

İstatistiksel analizler: Örneklerin analiz sonuçları tesadüf blokları deneme planına göre Windows SPPS 20.0 software istatistik paket programı (SPSS Inc., Chiago, IL, USA) kullanılarak yorumlanmıştır. Araştırma sonuçları tek yönlü varyans analizi kullanılarak değerlendirilmiş ve önem farklılıkları Duncan çoklu karşılaştırma testine göre belirlenmiştir.

\section{BULGULAR VE TARTIŞMA}

Patella sp. örneklerinin mevsimlere ve istasyonlara göre değişen su aktivitesi değer ortalamaları Şekil 1'de gösterilmiştir. Araştırma sonuçlarına göre, en düşük su aktivitesi değeri $0,9909 \pm 0,00$ olarak ilkbahar mevsiminde Sanayi istasyonundan toplanmış örneklerde tespit edilmişken, en yüksek su aktivitesi değer ortalamaları ise 0,9989 $\pm 0,00$ olarak kış mevsiminde Eynesil istasyonundan toplanan örneklerde tespit edilmiştir. Şekil 1'de de görüldüğü üzere istasyonlar arasındaki su aktivitesi değerleri arasinda istatiksel olarak önemli bir fark bulunmamakla birlikte; ilkbahar-sonbahar, yaz-sonbahar ve ilkbahar-kış mevsimlerinin su aktivitesi değer ortalamaları arasında anlamlı bir farkll1ık vardır $(\mathrm{p} \leq 0,05)$. Bilindiği üzere, su aktivitesi yüksek gıdalar mikroorganizmaların gelişmesine çok elverişli gıdalardır. $\mathrm{Bu}$ açıdan örnekler değerlendirildiğinde, su aktivitesi değerleri 1'e oldukça yakın olduğu için kolay bozulabilir ve patojen mikroorganizma gelişmesine elverişli gıdalar grubunda değerlendirilebilirler. $\mathrm{Bu}$ nedenle, örneklerin toplanma sonrası işleme ve depolama koşullarına dikkat edilmesi önem arz etmektedir. Literatürdeki çalışmalar incelendiğinde, midye örneklerinin su aktivitesi değerlerinin ölçülmediği fakat içerdikleri su oranlarının belirlendiği görülmektedir. $\mathrm{Bu}$ çalışmalardan biri olan Kaba \& Erkoyuncu (2005) tarafindan yapılan çeşitli şekillerde işlenen midyelerin (Mytilus galloprovincialis, Lamarck, 1819) su oranı \%83,3 olarak tespit edilmiştir. Turan \& Onay (2015) tarafindan yine aynı midye türlerinde yapılan farklı bir çalışmada çĭ̆ midyelerin su oranı ortalamaları $\% 84,23 \pm 0,82$ olarak, haşlanmıș midye örneklerinin su oranı ortalamaları ise $\% 76,18 \pm 0,39$ olarak tespit edilmiştir.

Farklı istasyonlardan alınan Patella sp. örneklerinin mevsimlere bağlı olarak gösterdiği $\mathrm{pH}$ değişimleri Şekil 2 'de gösterilmiştir. Araştırma sonuçlarına göre örneklerin $\mathrm{pH}$ ortalamalarının 6,87-7,76 değerleri arasında değiştiği görülmektedir. Elde edilen veriler istatiksel olarak incelendiğinde, mevsimlere bağlı olarak $\mathrm{pH}$ değişimleri arasında anlamlı bir farklılık bulunduğu görülmektedir. İlkbahar-kış, yaz-kış ve sonbahar-kış mevsimleri arasında $\mathrm{pH}$ ortalamaları arasında anlamlı bir farklılık bulunmaktadır $(\mathrm{p} \leq 0,05) . \quad \mathrm{pH}$ değerlerinin istasyonlara bağlı olarak değişimleri incelendiğinde ise, istasyonlar arasındaki farkın istatiksel olarak önemli olmadığı tespit edilmiştir $(p \leq 0,05)$. Çalışmamız sonuçlarına benzer olarak, Özalp (2008) tarafindan yapılan çalışmada midye örneklerinin $\mathrm{pH}$ değeri ortalamaları 7,03 $\pm 0,09$ olarak bulunmuştur.

Yapılan analizler sonucunda elde edilen Patella sp. örneklerine ait kuru madde, kül ve ham protein değerleri (\%) Tablo 1'de gösterilmiştir. Tablo 1'de gösterildiği gibi, Patella sp. örnekleri en yüksek kuru madde değerine tüm istasyonlar için yaz aylarında sahiptirler. En düşük kuru 
madde değeri \%16,68 $\pm 0,10$ kış mevsiminde Piraziz istasyonundan alınan örneklerde tespit edilmiş iken, en yüksek kuru madde değeri ise $\% 27,76 \pm 4,03$ olarak yaz mevsiminde Sanayi istasyonundan alınan örneklerde tespit edilmiştir. Temin edilen örnekler kuru madde değeri

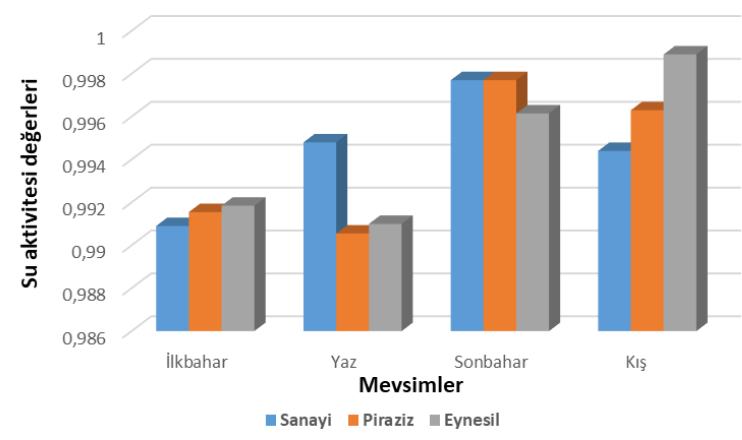

Şekil 1. Patella sp. örneklerinin su aktivitesi değerleri.

Figure. 1. Water activitiy values of the Patella sp. açısından değerlendirildiğinde; elde edilen değerlerin yalnızca mevsimsel olarak farkl1lık gösterirken, istasyonlar bazından herhangi bir farklılık gözlemlenmemiştir $(\mathrm{p} \leq 0,05)$

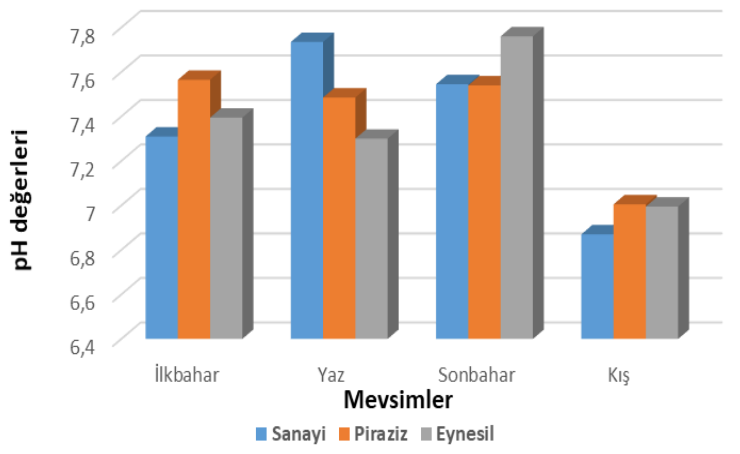

Şekil 2. Patella sp. örneklerinin $\mathrm{pH}$ değerleri.

Figure 2. pH values of the Patella sp.

Tablo 1. Patella sp. örneklerine ait kuru madde, kül ve ham protein değerleri.

Table 1. The dry matter, ash and protein values of the Patella sp.

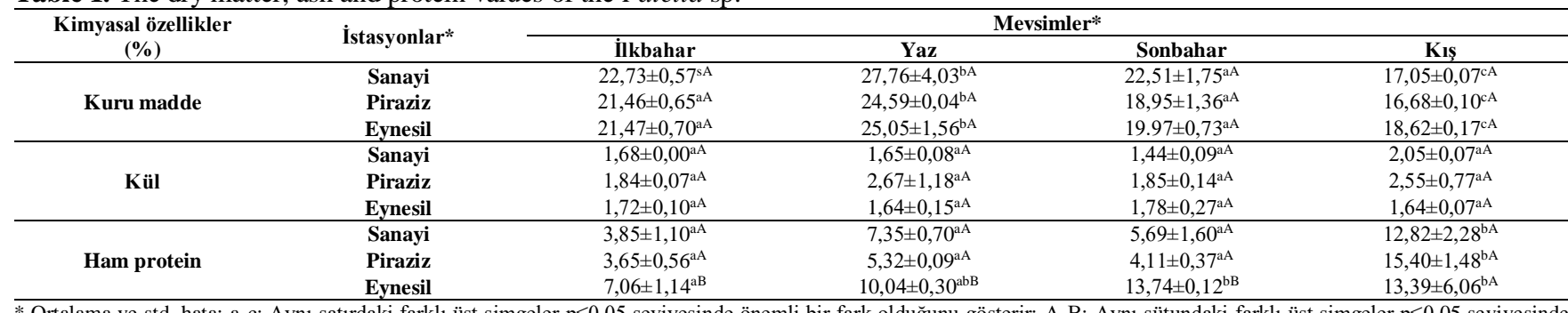

* Ortalama ve std. hata; a-c: Aynı satırdaki farklı üst simgeler $\mathrm{p} \leq 0,05$ seviyesinde önemli bir fark olduğunu gösterir; A-B: Aynı sütundaki farklı üst simgeler $\mathrm{p} \leq 0,05$ seviyesinde önemli bir fark olduğunu gösterir.

Tablo 2. Patella sp. örneklerinin renk değerleri

Table 2. Colour values of the Patella sp.

\begin{tabular}{|c|c|c|c|c|c|}
\hline \multirow{2}{*}{ Renk değerleri } & \multirow{2}{*}{ İstasyonlar* } & \multicolumn{4}{|c|}{ Mevsimler* } \\
\hline & & ilkbahar & Yaz & Sonbahar & KIS \\
\hline \multirow{3}{*}{${ }^{*} \boldsymbol{L}$} & Sanayi & $29,49 \pm 4,99^{\mathrm{abB}}$ & $26,72 \pm 2,35^{\mathrm{aB}}$ & $32,21 \pm 1,73^{\mathrm{bC}}$ & $22,88 \pm 1,49^{\mathrm{aA}}$ \\
\hline & Piraziz & $22,44 \pm 1,88^{\mathrm{aA}}$ & $24,70 \pm 3,32^{\mathrm{abA}}$ & $26,03 \pm 1,65^{\mathrm{bA}}$ & $20,95 \pm 3,92^{\mathrm{aA}}$ \\
\hline & Eynesil & $25,67 \pm 4,16^{\mathrm{aAB}}$ & $25,67 \pm 2,00^{\mathrm{aB}}$ & $29,14 \pm 3,72^{\mathrm{bB}}$ & $33,30 \pm 1,65^{\mathrm{cB}}$ \\
\hline \multirow[t]{2}{*}{$* a$} & Piraziz & $7,76 \pm 1,72^{\mathrm{bA}}$ & $3,34 \pm 0,93^{\mathrm{aA}}$ & $4,85 \pm 1,37^{\mathrm{aA}}$ & $9,36 \pm 1,62^{\mathrm{cA}}$ \\
\hline & Eynesil & $8,62 \pm 2,43^{\mathrm{abB}}$ & $5,73 \pm 0,71^{\mathrm{aB}}$ & $7,94 \pm 2,20^{\mathrm{abB}}$ & $13,27 \pm 0,67^{\text {bB }}$ \\
\hline \multirow[b]{2}{*}{$* b$} & Sanayi & $33,40 \pm 2,19^{\mathrm{bB}}$ & $18,03 \pm 2,72^{\mathrm{aC}}$ & $17,97 \pm 0,91^{\mathrm{aB}}$ & $32,58 \pm 0,83^{\mathrm{bB}}$ \\
\hline & Piraziz & $28,51 \pm 4,46^{\mathrm{cA}}$ & $11,23 \pm 2,31^{\mathrm{aA}}$ & $13,60 \pm 2,49^{\mathrm{bA}}$ & $29,00 \pm 2,67^{\mathrm{cA}}$ \\
\hline \multirow{3}{*}{$* \Delta E$} & Sanayi & $75,34 \pm 4,77^{\mathrm{bA}}$ & $72,53 \pm 1,61^{\mathrm{bA}}$ & $67,26 \pm 1,41^{\mathrm{aA}}$ & $81,18 \pm 1,79^{\mathrm{cA}}$ \\
\hline & Piraziz & $79,68 \pm 3,13^{\mathrm{bB}}$ & $72,73 \pm 2,79^{\mathrm{aA}}$ & $72,03 \pm 1,45^{\mathrm{aB}}$ & $81,56 \pm 2,49^{\mathrm{bA}}$ \\
\hline & Eynesil & $78,65 \pm 5,22^{\mathrm{cB}}$ & $72,61 \pm 2,11^{\mathrm{abB}}$ & $70,73 \pm 2,93^{\mathrm{aAB}}$ & $74,17 \pm 2,57^{\text {bB }}$ \\
\hline
\end{tabular}

* Ortalama ve std. hata; a-c: Aynı satırdaki farklı üst simgeler $\mathrm{p} \leq 0,05$ seviyesinde önemli bir fark olduğunu gösterir; A-C: Aynı sütundaki farklı üst simgeler $\mathrm{p} \leq 0,05$ seviyesinde önemli bir fark olduğunu gösterir.

Çalışma sonuçlarımıza benzer olarak, Süleyman (2016) tarafindan yapılan Doğu Karadeniz Bölgesi’ndeki kara midyenin (Mytilus galloprovincialis, Lamarck, 1819) biyokimyasal kompozisyonu hakkındaki çalışmada, midye örneklerinin kuru madde değer ortalamaları \%18,95 olarak belirlenmiştir. Bilindiği üzere gıdalarda kül analizi, örnek içeriğindeki inorganik madde miktarının belirlenmesi amacıyla yapılmaktadır. Tablo 1'de gösterilen kül değerleri incelendiğinde, kuru madde değerlerinin aksine en yüksek kül değerlerinin kış mevsiminde tespit edildiği

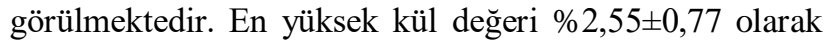
kış mevsiminde Piraziz istasyonundan elde edilen örneklerde belirlenmiş iken, en düşük kül değeri
$\% 1,64 \pm 0,15$ olarak yaz mevsiminde Eynesil istasyonundan elde edilen örneklerde belirlenmiştir. Kül değerlerindeki mevsimsel ve istasyona bağlı değişimler ise istatiksel olarak önemli bulunmamıştır $(\mathrm{p} \leq 0,05)$. Çalışmamız sonuçlarına benzer olarak, Özalp (2008) tarafindan midye örneklerinin kül miktarlarının $\% 1,16 \pm 0,53$ olarak bulunmuştur. Süleyman (2016) tarafindan yapılan bir başka çalışmada ise, midye örneklerinin kül miktar ortalamaları \%1,70 olarak belirlenmiştir. İstasyonlardaki protein değer ortalamaları arasında ise farklılık bulunmamaktadır $(\mathrm{p} \leq 0,05)$. En düşük ham protein değeri $\%$ 3,65 $\pm 0,56$ olarak ilkbahar ayında Piraziz istasyonunda tespit edilmiş iken, en yüksek protein oranı ise yine Piraziz 
istasyonundan yaz ayında \%15,40 $\pm 1,48$ olarak tespit edilmiştir. Çalışma sonuçlarımıza benzer olarak, Süleyman (2016) tarafından yapılan çalışmada midye örneklerinin ortalama protein değerleri \%12,04 olarak bulunmuştur. Özalp (2008) çalışmasında midye (Mytilus galloprovinciallis L.) etinin protein değer ortalamalarını ise \%10,80 olarak belirlemiştir. Bilindiği üzere, su ürünlerinin kimyasal kompozisyonlarının avlandıkları bölgeye, avlandıkları mevsime, beslenme durumuna, çevre sıcaklığına, iriliğine, yaşına, cinsiyetine ve diğer faktörlere bağlı olarak değişim göstermektedir. $\mathrm{Bu}$ durum, çalışmamızda elde ettiğimiz biyokimyasal sonuçlardaki farklılıkları açıklamaktadır. Ayrıca, ortamları olan su sıcaklığı, tükettiği besin maddeleri ve büyüme periyodu gibi çeşitli faktörler su ürünlerinin et verimini, mikrobiyal karakterizasyonunu ve biyokimyasal kompozisyonunu etkilemektedir (Orban vd., 2002). Bu durum çalışmamız sonuçlarında elde ettiğimiz mevsimsel farklılıkları açıklamaktadır.

Patella sp. örneklerine ait renk değerleri Tablo 2 'de gösterilmiştir. Analizlerde renk ölçümlerinde Hunter kolorimetresi kullanılmıştır. Hunter kolorimetresinde üç renk değeri vardır; * $a$ değeri kırmızı veya yeşilliği, * $b$ değeri sarılık veya maviliği, ${ }^{*} L$ değeri ise 0 (siyah) ve 100 (beyaz) arasındaki aydınlık derecesini ölçer. Buna göre örneklerin $* L$ değerleri incelendiğinde, en küçük $* L$ değerinin 22,44 $\pm 1,88$ olarak Piraziz istasyonunda İlkbahar mevsiminde, en yüksek $* L$ değerinin ise $33,30 \pm 1,65$ olarak Eynesil istasyonunda $K_{1}$ ş mevsiminde tespit edildiği görülmüştür. ${ }^{*} L$ değerleri arasında hem istasyonlar hem de mevsimlere göre istatiksel olarak anlamlı bir farklılık bulunmaktadır $(\mathrm{p} \leq 0,05)$. Tablo 2 'de görüldüğü gibi örneklerin *a değerleri 3,34 $\pm 0,93-13,27 \pm 0,67$ arasında değişmektedir. ${ }^{*} L$ değerine benzer olarak en yüksek $* a$ değeri de kış mevsiminde Eynesil istasyonunda tespit edilmiştir. Yine * $a$ değerleri arasında hem istasyonlar hem de mevsimlere göre istatiksel olarak anlamlı bir farklılık bulunmaktadır $\quad(\mathrm{p} \leq 0,05)$. Örneklerin $* b \quad$ değerleri incelendiğinde ise en yüksek $* b$ değerinin $35,58 \pm 4,37$ olarak diğer renk değerlerine benzer şekilde Kış mevsiminde Eynesil istasyonunda tespit edilmişken, en düşük * $b$ değeri 11,23 $\pm 2,31$ olarak yaz mevsiminde Piraziz istasyonunda tespit edilmiştir. Örneklerin renk değişimlerini ifade eden $* \Delta E$ değeri incelendiğinde ise; bu değerin $67,26 \pm 1,41-81,56 \pm 2,49$ arasında değiştiği görülmektedir. * $* E$ değer ortalamaları arasındaki değişim hem istasyonlara hem de mevsimlere göre istatiksel olarak anlamlı farklılık göstermektedir $(\mathrm{p} \leq 0,05)$.

Gıda ürünlerinin ve bulunduğu ortamın hijyen kontrollerinde ve gıdaların raf ömrünün tespitinde Toplam Mezofilik Aerobik Koloni (TMAB) sayısı kullanılmaktadır. TMAB sayısı arttıkça hijyen kalitesinin düştüğü ifade edilmektedir (Ünlütürk \& Turantaş, 2003). Gıda uzmanları ve midye dolma üzerine yapılan çalışmalara göre; meze tipi yiyeceklerde, hazır yemeklerde ve işlenmiş yumuşakçalarda (kabuklular-çift kabuklular)
TMAB sayısının 5 log kob/g'ı geçmemesi önerilmektedir (CFS, 2014). Su ürünleri yönetmeliği (2003)'e göre ise tüketilebilir sınır değer $6 \log$ kob/g'dır. Yapılan çalışmada Patella sp. örneklerine ait TMAB ortalama değerlerinin mevsimlere ve istasyonlara bağlı olarak değişimleri Şekil 3'de gösterilmiştir. Şekil 3'te de görüldüğü üzere, en yüksek TMAB bakteri sayısı kış mevsiminde 8,96 $\pm 0,19$ $\log \mathrm{kob} / \mathrm{g}$ olarak Eynesil istasyonunda tespit edilmiş iken, en düşük TMAB sayısı ise 7,98 $\pm 0,17 \mathrm{log} \mathrm{kob} / \mathrm{g}$ olarak Sanayi istasyonundan alınan örneklerde ilkbahar mevsiminde tespit edilmiştir. Çalışmamızda elde edilen TMAB sayıları tavsiye edilen ve tüketilebilir sınır değerlerin üzerindedir. İstatiksel olarak TMAB sayı ortalamaları değerlendirildiğinde, mevsimlerdeki ve istasyonlardaki TMAB ortalamaları arasında bir farklılık bulunmamaktadır $\quad(\mathrm{p} \leq 0,05)$. Literatür incelendiğinde Patella sp.'nin mikrobiyolojik özelliklerine ait çalışma örneğinin olmadığı görülmektedir. Çalışmamıza benzer olarak Güngörür \& Bostan (2019) yapılan bir çalışmada, TMAB sayısı açık mekânlarda satışa sunulan midye dolma örneklerinde 2,20-7,23 log kob/g (ortalama 6,27 log kob/g), kapalı mekânlarda satışa sunulan midye dolma örneklerinde ise 2,11-5,34 log kob/g (ortalama 4,27 log $\mathrm{kob} / \mathrm{g}$ ) arasında saptanmıştır. Turan \& Onay (2015) tarafindan yapılan bir başka çalışmada, çiğ midyelerin TMAB sayısı 3,58 log kob/g şeklinde belirlenmiş olup haşlandıktan sonra bu değerin ısıl işlem etkisiyle 3,16 log kob/g'a düştüğü belirlenmiştir. Kılınç vd., (2018) tarafindan yapılan farklı bir çalışmada ise, İzmir'in üç farklı bölgesinde $(A, B, C)$ kış mevsiminde satışa sunulan ve marketlerden rastgele örnekleme yöntemiyle alınan ve incelenen midye dolma örneklerinin TMAB sayılarının $<10-4,6 \times 10^{5} \mathrm{kob} / \mathrm{g}$ arasında değiştiği tespit edilmiştir.

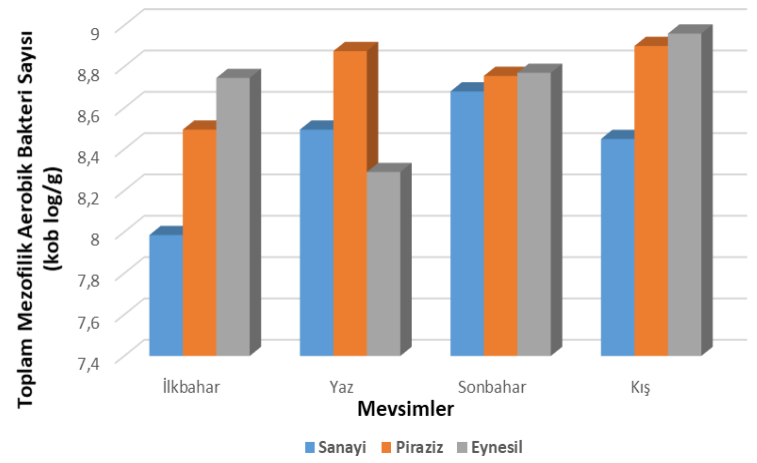

Şekil 3. Patella sp. örneklerinin Toplam Mezofilik Aerobik Bakteri sayıları

Figure 3. Total mesophilic aerobic bacteria values of the Patella sp.

Koliform grup Gram negatif bakteriler çeşitli gıdalarda sıkça aranan bakterilerdir. Temiz sularda avlanan balık ve diğer yenilebilir su ürünlerinde genellikle bulunmazlar. Fekal koliform grup bakterilerin varlığı, yetersiz işleme koşullarını veya işlemden sonraki 
bulaşmayı gösterir (Patır vd., 2011). Midyelerin kirli suların çok olduğu bölgelerde yetişmesinden dolayı, pek çok patojen mikroorganizmayı içermesi çiğ olmasının yanı sıra az pişmiş olarak tüketilmesinin çok büyük sağlık problemlerine yol açacağı bilinmektedir (İrkin vd., 2007). $\mathrm{Bu}$ açıdan değerlendirildiğinde, koliform bakteri sayısının çok düşük çıkması ise midyelerin bulundukları ve toplandıkları bölgenin fekal açıdan temiz olmasından kaynaklanmaktadır. Su Ürünleri Yönetmeliği (2003)'e göre çift kabuklu yumuşakçalar için maksimum sınır değer $2 \log$ kob/g'dır. Çalışmamızda koliform grup bakteri sayısının $\quad 1,15 \pm 0,21-2,38 \pm 0,11 \quad \log \quad \mathrm{kob} / \mathrm{g}$ değerleri arasında değiştiği tespit edilmiştir. Bu değerler Su Ürünleri Yönetmeliğinde belirtilen sınır değerler içerisindedir. Şekil 4'te örneklerin koliform bakteri sayısı gösterilmiştir. Koliform bakteri sayı ortalamaları arasında hem mevsimsel hem de istasyonlara bağlı olarak istatiksel olarak farklılık bulunmamaktadır $(\mathrm{p} \leq 0,05)$.

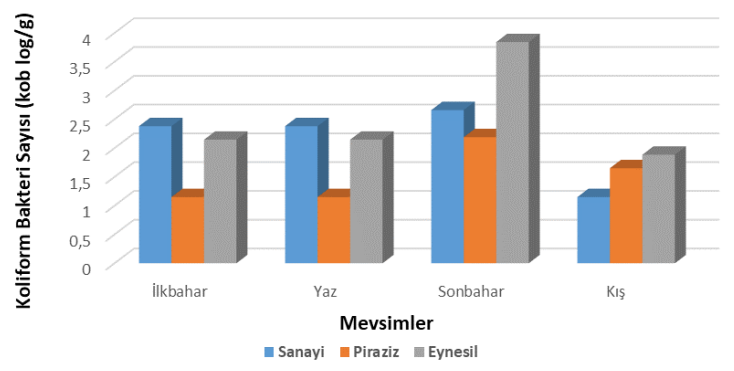

Şekil 4. Patella sp. örneklerinin koliform bakteri sayısı.

Figure 4. Coliform bacteria number of the Patella sp.

E. coli, Enterobacteriaceae familyasina ait bakteridir. Hijyen indikatörü olması itibariyle gıda hijyeni kontrollerinde önem taşır. Bunun yanı sıra bazı E. coli suşlarının patojenik özellik gösterdiği de bilinmektedir (Güngörür \& Bostan, 2019). Çalışmamızda, örneklerin $E$. coli analizleri En Muhtemel Sayı yöntemine göre yapılmıştır. Patella sp. örneklerine ilişsin E. coli analiz sonuçları ise Tablo 3'te gösterilmiştir ve analiz sonuçları EMS/g olarak verilmiştir. Tablo 3'deki sonuçlar incelendiğinde en düşük $E$. coli ortalama değeri 0,30 EMS/g olarak tespit edilmişken, en yüksek $E$. coli değeri ise 24,00 EMS/g olarak tespit edilmiştir. Türk Gıda Kodeksi Mikrobiyolojik Kriterler Yönetmeliği'nde tüketime hazır her türlü salata, şarküteri ürünleri ve soğuk mezeler vb. gıda ürünlerinde $E$. coli limiti 1 x $10^{1} \mathrm{kob} / \mathrm{g}(1$ $\log \mathrm{kob} / \mathrm{g}$ ) olarak belirtilmiştir (TGK, 2011). Yapılan farklı bir çalışmada, midye etlerinin çiğ olarak yenebildiği gibi hafif pișmiş durumda tüketildiği, bu nedenle canlı midyelerde $E$. coli $10^{2} \mathrm{kob} / \mathrm{g}^{\prime} 1$ geçmiyorsa işleme alınabileceği belirtilmektedir (İrkin vd., 2007). Buna göre örneklerimizin E. coli değerleri mevsimlere ve istasyonlara göre belirtilen limitleri aştı̆̆ görülmektedir.
Tablo 3. Patella sp. örneklerinin E.coli sonuçları (EMS/g).

Table 3. E.coli results of Patella sp.

\begin{tabular}{clcccc}
\hline $\begin{array}{c}\text { Mikrobiyolojik } \\
\text { Analizler }\end{array}$ & \multicolumn{5}{c}{ Mevsimler } \\
\cline { 2 - 6 } E.stasyon & Ilkbahar & Yaz & Sonbahar & Kış \\
\hline \multirow{2}{*}{.coli } & Sanayi & 2,30 & 15,00 & 24,00 & 0,74 \\
& Piraziz & 0,30 & 7,50 & 0,30 & 0,36 \\
& Eynesil & 0,30 & 0,92 & 15,00 & 0,74 \\
\hline
\end{tabular}

Araştırmamızda elde edilen toplam psikrofilik bakteri analizleri sonucunda, en yüksek psikrofil bakteri sayısının yaz mevsiminde Sanayi istasyonunda 2,66 $\pm 0,02$ $\log \mathrm{kob} / \mathrm{g}$ olarak, en düşük bakteri sayısı yine Sanayi istasyonunda $1,35 \pm 0,48 \log \mathrm{kob} / \mathrm{g}$ olarak tespit edilmiştir. Şekil 5'de Patella sp. örneklerinin toplam psikrofilik bakteri sayıları gösterilmiştir. Araştırma sonuçları istatiksel olarak yorumlandığında hem mevsimsel hem de istasyonlardan kaynaklı olarak anlamlı bir farklılık bulunmamaktadır $(\mathrm{p} \leq 0,05)$. Araştırma sonuçlarına benzer olarak, Turan vd., (2012) 3,23 log kob/g psikrofil bakteri yüküne sahip olan midyelerin 4 . gün sonundaki yüklerini streç filmlenen ve suda saklanan gruplarda 6,07-6,17 log kob/g olarak bulmuştur.

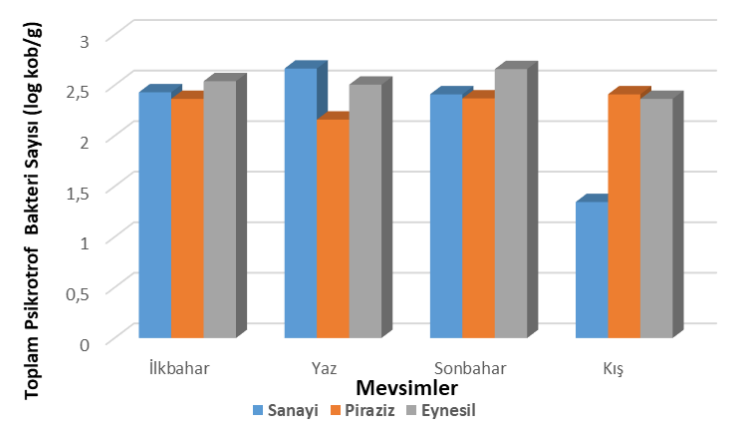

Şekil 5. Patella sp. örneklerinin toplam psikrofilik bakteri sayısı. Figure 5. Total psychrophil bacteria number of the Patella sp.

Patella sp. örneklerine ait toplam maya-küf sonuçları Şekil 6'da gösterilmiştir. Şekil 6'da da görüldüğü üzere; en yüksek maya-küf sayısı Piraziz istasyonunda $5,09 \pm 0,03$ log kob/g olarak kış mevsiminde tespit edilmişken, en yüksek maya-küf ortalama değeri ise yine Piraziz istasyonunda $6,76 \pm 0,03 \mathrm{log} \mathrm{kob} / \mathrm{g}$ olarak tespit edilmiştir. İstatiksel olarak, istasyonlardaki ortalama maya-küf sayı değerleri arasında anlamlı bir farklılık bulunamamaktadır $(p \leq 0,05)$. Mevsimsel olarak ise ortalama maya-küf değerleri arasındaki fark anlamlı olup, sonbahar ve kış mevsimindeki değişimler arasındaki farklılıklar istatiksel olarak önemlidir $(\mathrm{p} \leq 0,05)$. Kılınç vd., (2018) tarafindan yapılan İzmir'in farklı bölgelerinde satıșa sunulan midye dolmalarda maya ve küf değerlerinin en düşük $<10$ ve en yüksek $6,0 \times 10^{1} \mathrm{kob} / \mathrm{g}$ arasında değişim gösterdiği belirlenmiştir. İrkin vd., (2007) Çanakkale bölgesini kapsayan bir çalışmasında, donmuş örneklerinde toplam maya küf sayısı 1,0x10² kob/g olarak bulunmuştur. Çalışmada elde ettiğimiz maya-küf değerlerinin diğer çalışmalara oranla daha yüksek olduğu görülmektedir. $\mathrm{Bu}$ 
durumun; örneklerin toplandığı alana, çevresel faktörlere ve mevsimlere bağlı olduğu düşünülmektedir.

Sonuç olarak, literatürdeki çalışmalardan farklılıkla, et kalitesi ve tüketim uygunluğu açısından Patella sp. örneklerinin değerlendirildiği çalışmamızda, örneklerin fizikokimyasal açıdan tüketime uygunluk gösterdiği tespit edilmiştir. Fakat örnekler mikrobiyolojik olarak tüketim sınırları üzerinde değerlere sahiptirler ve bu değerler istasyonlar ile mevsimlere bağlı olarak da değişiklik göstermektedir. Mikrobiyolojik değerler üzerinde, avlanma bölgesinin, su ve çevre sıcaklığı ile su mikrobiyolojik kalitesinin etkili olduğu düşünülmektedir. Ayrıca gıda güvenliği açısından midye tüketimi genel olarak değerlendirildiğinde, önemli bir parametre olan ağır metal yoğunluğu da göz önünde bulundurulmalıdır. $\mathrm{Bu}$ kapsamda, Patella sp.'nin gida olarak tüketilmesinde gelecekteki çalışmalarda ağır metal içeriklerinin de belirlenmesi faydalı olacaktır.

\section{TEŞEKKÜR}

$\mathrm{Bu}$ çalışma "Giresun Kıyı Şeridindeki Patella sp.'nin Et Kalitesi Değişiminin Mevsimsel Olarak Belirlenmesi" başlıklı Yüksek Lisans Tez çalışmasından üretilmiştir.

\section{KAYNAKLAR}

Akkan, T. \& Çolaker, F. (2020). Determining the Bacteriological Pollution Level of Gelevera Creek, Giresun. J. Anatolian Env. and Anim. Sciences, 5(4), 691-695. DOI: $10.35229 /$ jaes. 818132

Akkan, T. \& Mutlu, C. (2016.) Determination of antibiotics resistance levels in Enterobacteriaceae isolated from Giresun Coasts. Turkish Journal of Agriculture-Food Science and Technology, 4(8), 640-650. DOI: 10.24925/turjaf.v4i8.640-650.721

Akkan, T. \& Topkaraoğlu, T. (2019). Determination of antibiotic resistance levels of Escherichia coli isolates obtained from freshwater sources: Batlama Creek. Journal of Anatolian Environmental and Animal Sciences, 4(3), 539544. DOI: $10.35229 /$ jaes. 650210

Akkan, T. (2017). Antibiotic resistance case study: Enterobacteriaceae isolated from Batlama Creek in Giresun, Turkey. Turkish Journal of Agriculture Food Science and Technology, 5(8), 969-972. DOI: $10.24925 /$ turjaf.v5i8.969972.1262

Akkan, T., Mehel, S. \& Mutlu, C. (2019). Determining the level of bacteriological pollution level in Yağlidere Stream, Giresun. Journal of Limnology and Freshwater Fisheries Research, 5(2), 83-88. DOI: $10.17216 /$ limnofish.450722

Anonim. (2003). Su ürünleri yönetmeliği. Resmî Gazete, (25052)
AOAC. (1984). Officials methods of analysis, Washington DC, USA.

CFS. (2014). Microbiological Guidelines for Foods (For ready-to-eat food in general and specific food items) August 2014 (revised), Food and Environmental Hygiene Department, Center for Food Safety, USA.

Coleman, R.A., Underwood, A.J., Benedetti-Cecchi, L., Åberg, P., Arenas, F., Arrontes, J., Castro, J., Hartnoll, R.G., Jenkins, S.R., Paula, J., Della Santina, P. \& Hawkins, S.J. (2006). A continental scale evaluation of the role of limpet grazing on rocky shores. Oecologia, 147, 556564.

FDA. (1995). Bacteriolological Analytical Manual. Food and Drug Administration 16 th edition. AOAC Int. Gaithersburg.

Göğüș, A.K. \& Kolsarıcı, N. (1992). Su Ürünleri Teknolojisi. Ankara Üniversitesi Ziraat Fakültesi Yayınları: 1243, Ders Kitabı: 358, Ankara, 261 s.

Gözler A.M., Engin S., Çiloğlu E. \& Şahin C. (2003). Deniz salyangozlarından Patella caerulea L., 1758'in Doğu Karadeniz (Rize) kıyılarında et verimi ve mevsimsel değișimi, XII.Ulusal Su Ürünleri Sempozyumu, 2-5 Eylül 2003, Elazığg, Türkiye, 281-285.

Güngör, M. (2011). Türkiye denizlerinde bulunan Çin şapkast (Patella caerulea Linnaeus, 1758) populasyonlarının genetik incelenmesi. Yüksek Lisans Tezi, Mustafa Kemal Üniversitesi Fen Bilimleri Enstitüsü. Hatay, Türkiye, 49s.

Güngörür, M.N. \& Bostan, K. (2019). İstanbul'da Satışa Sunulan midye dolmaların mikrobiyolojik kalitesi. Aydın Gastronomy, 3(1), 55-63.

İnal, T. (1992). Besin Hijyeni Hayvansal Gidaların Kontrolü, Final Ofset, İstanbul, 783s.

İrkin, R., Korukluoğlu, M. \& Tavşanlı H. (2007). İhracata yönelik hazırlanan bazı deniz ürünlerinin mikrobiyal özellikleri. Türk Hijyen ve Deneysel Biyoloji Dergisi, 64, 26-30.

Jenkins, S.R., Coleman, R.A., Della Santina, P., Hawkins, S.J., Burrows, M.T. \& Hartnoll, R.G. (2005). Regional scale differences in the determinism of grazing effects in the rocky intertidal. Marine Ecology Progress Series, 287, 77-86. DOI: 10.3354 / meps 287077

Kaba, N. \& Erkoyuncu, İ. (2005). Çeșitli şekillerde işlenen midyelerin (Mytilus galloprovincialis Lamarck, 1819) donmuş depolanması sırasında duyusal ve kimyasal kalitelerinin belirlenmesi. Atatürk Üniversitesi Ziraat Fakültesi Dergisi, 36(2), 193-200.

Kılınç, B., Atalay, S.D. \& Şahin, V.C. (2014). Midye dolmanın gıda güvenliği açısından farkındalığının belirlenmesi. 4.Geleneksel Gidalar Sempozyumu, 17-19 Nisan 2014, Adana, Türkiye, 194-197.

Kılınç, B., Yılmaz, B.Ş. \& Gören, B. (2018). İzmir'in farklı bölgelerinde satışa sunulan midye dolmaların mikrobiyolojik kalitesi. Süleyman Demirel Üniversitesi Eğirdir Su Ürünleri 
Fakültesi Dergisi, 14(4), 276-290. DOI: 10.22392/egirdir.403570

Mol, T.S. (2006). Fayda ve riskleriyle midye. Dünya Gıda Dergisi, 5, 83-88.

Mutlu, C., Eraslan Akkan, B. \& Verep, B. (2018). The heavy metal assessment of Harsit Stream (Giresun, Turkey) using multivariate statistical techniques. Fresenius Environmental Bulletin, 27, 12B, 9851-9858.

Orban, E., Di Lena, G., Nevigato, T., Casini, I., Marzetti, A. \& Caproni, R. (2002). Condition index and chemical composition of mussels (Mytilus galloprovincialis) cultured in two diVerent Italian sites. Food Chemistry, 77, 57-65. DOI: 10.1016/S0308-8146(01)00322-3

Özalp, B. (2008). Bazı su ürünlerinin bileşimi ve değişik teknolojik özelliklerinin belirlenmesi üzerine bir araştırma. Yüksek Lisans Tezi, Selçuk Üniversitesi Fen Bilimleri Enstitüsü, Konya, Türkiye, 97s.

Özen, F. \& Çoșkun, F. (2014). Effect of herbal extracts addition on microbial composition and sensory properties of Tekirdag meatballs. Journal of Tekirdag Agricultural Faculty, 11(3), 100-109.

Öztürk, B. \& Ergen, Z. (1999). Patella species (Archaeogastropoda) distributed in Saros Bay (Northest Aegean Sea). Turkish Journal of Zoology, 23(EK2), 513-520.

Patır, B., Özpolat, E., Şeker, P. \& Yalçın, H. (2011). Vakum ambalajlı gökkuşağı alabalığı (Oncorhynchus mykiss Walbaum, 1792) havyarının üretimi ve muhafazası sirasında mikrobiyolojik kalitesinde meydana gelen değişimler. FÜ Sağllk Bilimleri Veteriner Dergisi, 25(1), 31-36.

Polat, N. \& Akkan, T. (2016). Assessment of heavy metal and detergent pollution in Giresun Coastal Zone, Turkey. Fresenius Environmental Bulletin, 25(8), 2884-2890.

Sipahi, N., Mutlu, C. \& Akkan, T. (2013). Giresun İlinde tüketime sunulan bazı balıklardan izole edilen Enterobacteriaceae üyelerinin antibiyotik ve ağır metal dirençlilik düzeyleri. Glda, 38(6), 343-349. https://doi.org/10.5505/gida.2013.55264

Süleyman, B. (2016). Doğu Karadeniz Bölgesi'ndeki kara midyenin (Mytilus galloprovincialis, Lamarck, 1819) biyokimyasal kompozisyonu ve et kalitesinin mevsimsel değişiminin belirlenmesi. Yüksek Lisans Tezi, Recep Tayyip Erdoğan Üniversitesi, Fen Bilimleri Enstitüsü, Rize, Türkiye, 92s.

TGK (2011). Türk Gida Kodeksi Mikrobiyolojik Kriterler Yönetmeliği (Resmi Gazete, Tarihi: 29.12.2011 Resmi Gazete Sayısı: 28157 (3.mükerrer).

Turan, H. \& Onay, R.T. (2015). Modifiye atmosfer paketleme uygulanan midyelerin (Mytilus galloprovincialis, Lamarck 1819) buzdolabı $\left(4 \pm 2^{\circ}\right.$ C) koşullarında raf ömrünün tespiti. Journal of Food and Health Science, 1(4), 185198. DOI: $10.3153 /$ JFHS15018
Turan, H., Kocatepe, D., Altan, C.O. \& Erkoyuncu, İ. (2012). Soğukta saklanan tüketime hazır midyelerin (Mytilus galloprovincialis L. 1819) besin kompozisyonu ve kalite kriterlerinin incelenmesi. 11. Hatay Gida Kongresi, 10-12 Ekim 2012, Hatay, Türkiye, 364s.

TÜİK. (2020). Su Ürünleri İstatistikleri, Tarım ve Orman Bakanlığı, Balıkçılık ve Su Ürünleri Genel Müdürlüğü, Ankara.

Uncumusaoglu, A.A., Sengul, U. \& Akkan, T. (2016). Environmental contamination of heavy metals in the yaglidere stream (Giresun), Southeastern Black Sea. Fresenius Environmental Bulletin, 25, 5492-5498.

Uncumusaoğlu, A.A. \& Akkan, T. (2017). Assessment of Stream Water Quality Using Multivariate Statistical Techniques. Polish Journal of Environmental Studies, 26(4), 1715-1723. DOI: $10.15244 /$ pjoes/68952

Ünlütürk, A. \& Turantaş, F. (2003). Mikrobiyal bulaşma kaynakları. Gida mikrobiyolojisi. Meta Basım Matbaacılık Hizmetleri, Bornova, İzmir. ISBN: 975-483-383-4. 